\title{
Trophic niche overlap between flatfishes in a nursery area on the Portuguese coast*
}

\author{
HENRIQUE N. CABRAL ${ }^{1}$, MARTA LOPES ${ }^{1}$ and RALF LOEPER ${ }^{2}$ \\ ${ }^{1}$ Instituto de Oceanografia, Faculdade de Ciências da Universidade de Lisboa, Campo Grande, 1749-016 Lisboa, \\ Portugal. E-mail: hcabral@fc.ul.pt \\ 2 Johannes-Gutenberg Universität Mainz, Saarstrass 21, 55099 Mainz, Germany
}

\begin{abstract}
SUMMARY: The diets and the trophic niche overlap between seven flatfish species were studied in a coastal nursery adjoining to the Tagus estuary (Portugal). Fish were sampled monthly, from March to November 1999, using a beach seine. Arnoglossus imperialis (Rafinesque, 1810), Arnoglossus laterna (Walbaum, 1792) and Arnoglossus thori Kyle, 1913, fed mainly on crustaceans. The diets of Buglossidium luteum (Risso, 1810) and Dicologoglossa cuneata (Moreau, 1881) were mainly composed of Bivalvia and Polychaeta, while for Scophthalmus rhombus (Linnaeus, 1758) the main food items were Mysidacea and Teleostei. The diet of Pegusa lascaris (Risso, 1810) was mainly composed by Cumacea, Bivalvia, Decapoda and Amphipoda. Based on diet similarities two main groups were identified: one composed of A. imperialis, A. laterna, $A$. thori and S. rhombus, and the other grouping B. luteum, P. lascaris and D. cuneata. For the most common flatfishes, a similar pattern of diet seasonal variation was found, such that Amphipoda presented higher indices values in the period from March to June, while from July to November, Decapoda were more abundant. Although high values of diet overlap were obtained among some of the species, the main items in the diet of flatfishes are probably the most abundant prey in this coastal area, which suggests a generalist and opportunistic utilization of these food resources. Furthermore, niche overlap between these species is probably minimized by differences in resource use in other niche dimensions, namely time and space.
\end{abstract}

Key words: niche overlap, feeding ecology, flatfish, nursery, coastal areas.

RESUMEN: SOLAPAMIENTO DEL NICHO TRÓFICO EN UN ÁREA DE CRÍA EN LA COSTA PORTUGUESA. - Se estudiaron las dietas y el solapamiento de nicho trófico de siete especies de peces planos en un área costera adyacente al estuario del río Tajo (Portugal). Los peces se muestrearon mensualmente, de marzo a noviembre de 1999 usando un arte de cerco de playa. Arnoglossus imperialis (Rafinesque, 1810), Arnoglossus laterna (Walbaum, 1792) y Arnoglossus thori Kyle, 1913, se alimentan principalmente de crustáceos. La dieta de Buglossidium luteum (Risso, 1810) y Dicologoglossa cuneata (Moreau, 1881) estuvo compuesta, principalmente, por bivalvos y poliquetos, mientras que para Scophthalmus rhombus (Linnaeus, 1758) el principal alimento fueron misidáceos y teleósteos. La dieta de Pegusa lascaris (Risso, 1810) estuvo compuesta, principalmente, por cumáceos, bivalvos, decápodos y amfípodos. En base a las similaridades de la dieta se identificaron dos grupos: uno compuesto por A. imperialis, A. laterna, A. thori y S. rhombus, y el otro por B. luteum, P. lascaris y D. cuneata. Se encontró una pauta similar de variación estacional de la dieta para los peces planos más comunes, destacando que los amfípodos presentan índices más altos en los periodos de marzo a junio, mientras que los decápodos fueron más abundantes en las dietas de julio a noviembre. Aunque se obtuvieron altos valores de solapamiento en las dietas entre algunas de las especies, los principales organismos en las dietas de los peces planos son probablemente las presas más abundantes en este área costera, lo que sugiere una utilización generalista y oportunista de los recursos alimenticios. Además, el solapamiento del nicho entre estas especies está probablemente minimizado por diferencias en el uso de los recursos en otras dimensiones del nicho, a saber tiempo y espacio.

Palabras clave: solapamiento de nicho, ecología trófica, peces planos, cría, áreas costeras.

*Received September 6, 2001. Accepted January 17, 2002. 


\section{INTRODUCTION}

Coastal areas have long been recognized as important nursery areas for fish (e.g. Blaber and Blaber, 1980; Lenanton, 1982; Costa and Bruxelas, 1989). These areas generally offer a high abundance of food resources, protection from predators and good conditions for a rapid growth for juvenile fishes (e.g. Miller and Dunn, 1980; Haedrich, 1983). Most of the studies of coastal nurseries have often centred on estuarine environments and the structure and dynamics of fish assemblages have been well documented in many areas (e.g. Elliott and Dewailly, 1995; Mathieson et al., 2000).

Fish juveniles are usually concentrated in particular areas where extreme high densities are observed, which emphasize the relevance of resource partitioning in the coastal fish assemblages. Several authors suggested that food partitioning is very common, and is more important than habitat partitioning in the structuring of fish assemblages (e.g. Schoener, 1974; Ross, 1986). Generally, food partitioning should be found when resources are limited and thus the potential for competition is high (Thorman and Wiederholm, 1986; Putman, 1994).

Few studies focused the trophic relationships between fishes in south European coastal non-estuarine areas. On the Portuguese coast, Cabral et al. (2000) described the structure of a coastal fish assemblage, such that most of the 60 species recorded in the area used it as a nursery ground. Several flatfish species occurred within this assemblage, some of which presented high abundance values, namely Arnoglossus laterna (Walbaum, 1792), Arnoglossus thori Kyle, 1913, Buglossidium luteum (Risso, 1810), Dicologoglossa cuneata (Moreau, 1881), Scophthalmus rhombus (Linnaeus, 1758) and Pegusa lascaris (Risso, 1810). The occurrence of flatfish juveniles was highly seasonal, with their abundance peaks limited to a few months period (Cabral et al., 2000).

Studies on the feeding ecology of flatfish species have been conducted mainly in north Europe and the Mediterranean, and have especially focused on commercially important species, such as Solea solea (Linnaeus, 1758), Pleuronectes platessa Linnaeus, 1758, Platichthys flesus (Linnaeus, 1758) and Limanda limanda (Linnaeus, 1758) (e.g. Ramos, 1981; Summers, 1980; Poxton et al., 1983; Lagardère, 1987; Knust, 1990; Aarnio et al., 1996). Although the Portuguese coast is a zoogeographic area of particular interest, since many North Atlantic and African-Mediterranean flatfish species are present at its southern and northern distribution limits, respectively (Quero et al., 1986; Cabral, 2000a), little work has been done in these areas.

The present study compared the diets of individuals of seven flatfish species, mainly juveniles, and evaluated the trophic niche overlap between these species in the coastal areas adjoining the Tagus estuary (Portugal).

\section{MATERIAL AND METHODS}

\section{Study area}

The study area is located in the coastal zone adjacent to the Tagus estuary near Fonte da Telha $\left(39^{\circ} 25^{\prime} \mathrm{N}, 9^{\circ} 15^{\prime} \mathrm{W}\right)$ (Fig. 1). It is a shallow sandy area with a tidal range of ca. $4 \mathrm{~m}$. Seawater temperature varies between ca. $13^{\circ} \mathrm{C}$, in winter, and ca. $19^{\circ} \mathrm{C}$, in summer.

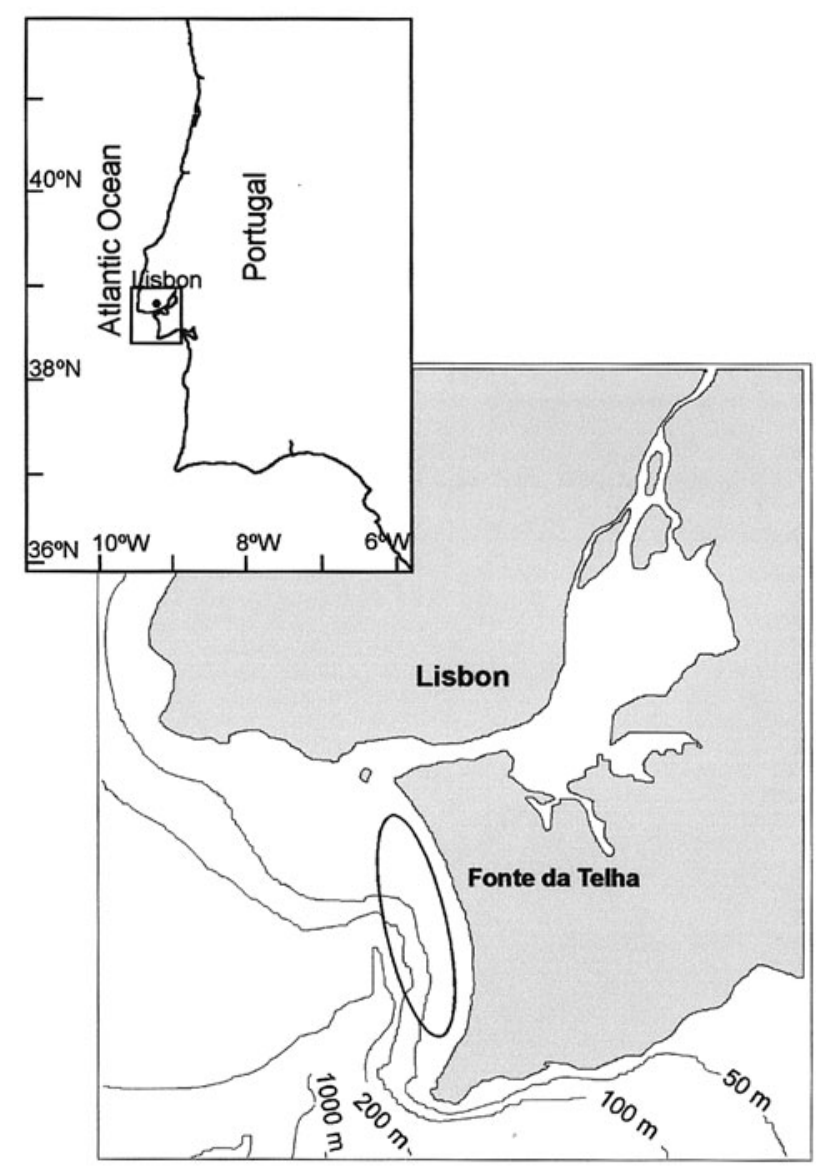

FIG. 1. - Location of the sampling area on the Portuguese coast. 
TABLE 1. - Number of stomachs (per period) and range of lengths of the individuals analyzed for each species.

\begin{tabular}{lccc}
\hline Species & $\begin{array}{c}\text { Number of stomachs } \\
\text { March-June July-November }\end{array}$ & Total length (mm) \\
\hline A. imperialis & 37 & 43 & $89-179$ \\
A. laterna & 89 & 113 & $74-156$ \\
A. thori & 52 & 64 & $99-170$ \\
B. luteum & 79 & 97 & $51-120$ \\
D. cuneata & 17 & 141 & $86-255$ \\
S. rhombus & 7 & 41 & $66-156$ \\
$P$. lascaris & 14 & 142 & \\
\hline
\end{tabular}

\section{Sampling procedures and data analysis}

Fish were sampled monthly, from March 1999 to November 1999, using a $50 \mathrm{~m}$ beach seine with 10 $\mathrm{mm}$ mesh size. Fish were identified, counted, measured (total length to the nearest $1 \mathrm{~mm}$ ) and weighed (wet weight with $0.01 \mathrm{~g}$ precision). Stomachs were removed and their contents preserved in $4 \%$ buffered formalin for later identification. Diet characterization was based on only the stomach contents (and not all the digestive tract), to avoid overestimation of prey with exoskeletons or other hard structures.

The stomach contents of 80 Arnoglossus imperialis (Rafinesque, 1810), 202 A. laterna, 116 A. thori, 176 B. luteum, 158 D. cuneata, 48 S. rhombus and 156 P. lascaris were analyzed (Table 1). Each prey item was identified to the lowest taxonomic level possible, counted and weighed (wet weight with $0.001 \mathrm{~g}$ precision). The relative importance of each prey item in the diet was expressed as a percent of numerical abundance (NI: numerical index), occurrence of food items in stomachs (OI: occurrence index) and weight (GI: gravimetrical index) (Hyslop, 1980).

A cluster analysis was performed in order to group species based on diet similarity. The Euclidean distances and the weighed pair-group average clustering method were determined based on the GI values (e.g. Cabral and Murta, 2001).

Diet differences according to season were tested using the G-test of independence (Zar, 1996), with a 0.05 significance level. Two periods were considered: March to June and July to November. This analysis was performed only for the species that were abundant in the two periods (i.e. A. imperialis, A. laterna, A thori and B. luteum). These periods were established based on the occurrence patterns of the flatfishes according to Cabral et al. (2000).
Diet overlap was measured using the Schoener index (SI), defined as

$$
S I=1-0.5\left(\sum_{i=1}^{n}\left|p_{i_{A}}-p_{i_{B}}\right|\right),
$$

where $p_{i_{A}}$ and $p_{i_{B}}$ were the numerical frequencies of item $i$ in the diet of species $A$ and $B$, respectively (Linton et al., 1981). Values of diet overlap vary from 0 , when no food is shared, to 1 , when there is the same proportional use of all food resources. Although there are no critical levels with which overlap values can be compared, Wallace (1981) and Wallace and Ramsey (1983) suggested that values higher than 0.6 should be considered as biologically significant.

\section{RESULTS}

\section{General food habits}

A. imperialis, A. laterna and A. thori fed mainly on crustaceans. For A. imperialis, Mysidacea was the most important food item, while for A. laterna Amphipoda, Decapoda and Mysidacea presented similar indices values. Decapoda, Polychaeta, Mysidacea and Amphipoda were the main prey of $A$. thori (Table 2).

The diets of $B$. luteum and D. cuneata were mainly composed of Bivalvia (only siphons were ingested) and Polychaeta. For B. luteum, Amphipoda was also an important item in the diet (Table 2).

For $S$. rhombus, the relative importance of the items in the diet was particularly different according to the index used. Mysidacea was the main prey by number (NI), while Teleostei was the main prey by weight (GI). Considering the OI, Decapoda was also an important prey in the diet of $S$. rhombus (Table 2).

The diet of $P$. lascaris was mainly composed of Cumacea, Bivalvia, Decapoda and Amphipoda (Table 2).

According to the dendogram obtained from the cluster analysis performed on GI data, two main clusters were obtained: one composed of $A$. imperialis, A. laterna, A. thori and S. rhombus, and the other grouping B. luteum, P. lascaris and D. cuneata (Fig. 2).

\section{Seasonal variation of diets}

For all the species considered in the seasonal analysis, i.e. A. imperialis, A. laterna, A. thori and 


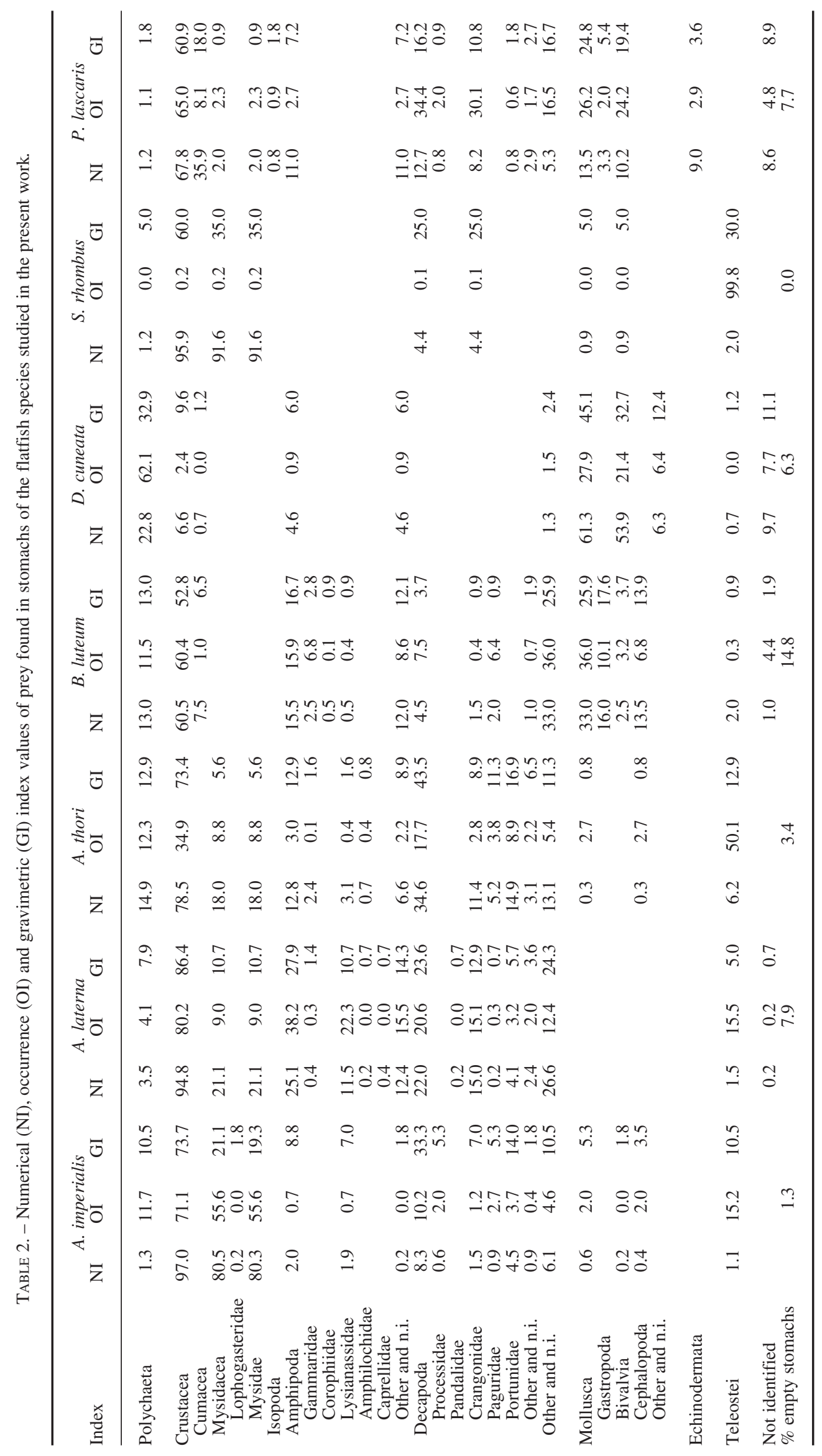




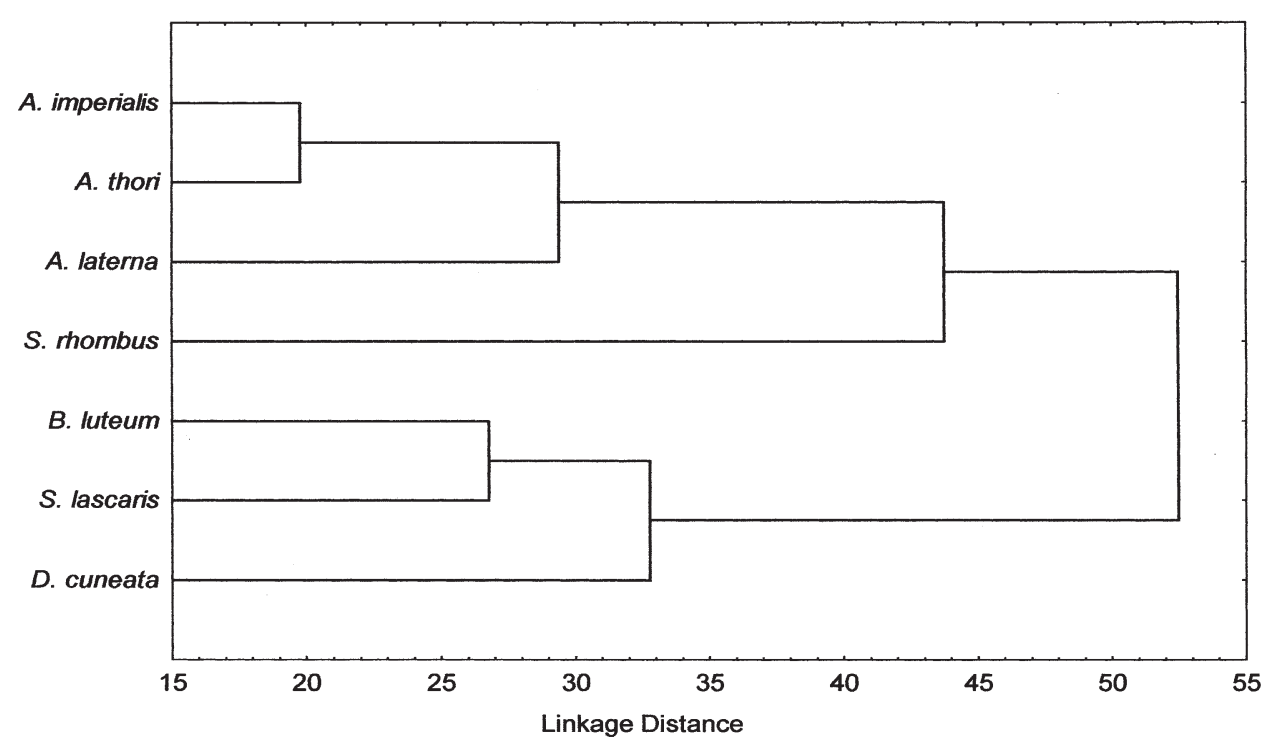

FIG. 2. - Dendrogram resulting from the cluster analysis performed on stomach contents data of the flatfish species studied in the present work.

B. luteum, diet varied according to season $(\mathrm{G}=41.5$, $\mathrm{P}<0.05 ; \mathrm{G}=21.9, \mathrm{P}<0.05 ; \mathrm{G}=86.2, \mathrm{P}<0.05 ; \mathrm{G}=17.0$, $\mathrm{P}<0.05$; respectively).

Although the relative importance of each item varied considerably according to the index used, it can be noticed for all the species, that Amphipoda presented higher indices values in the period from

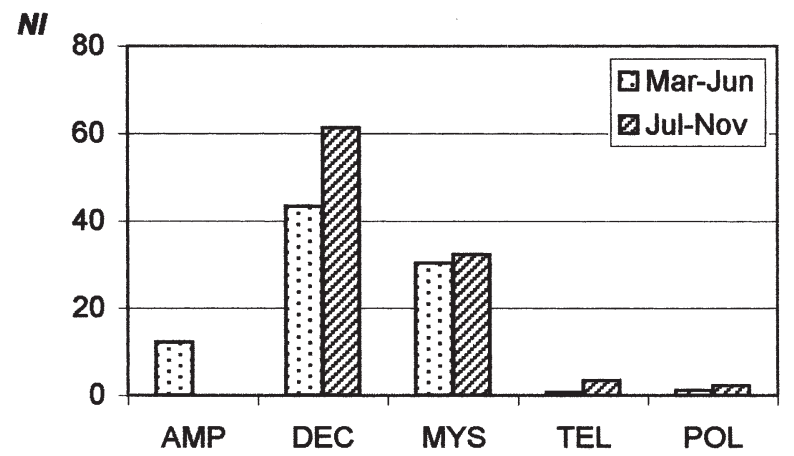

GI

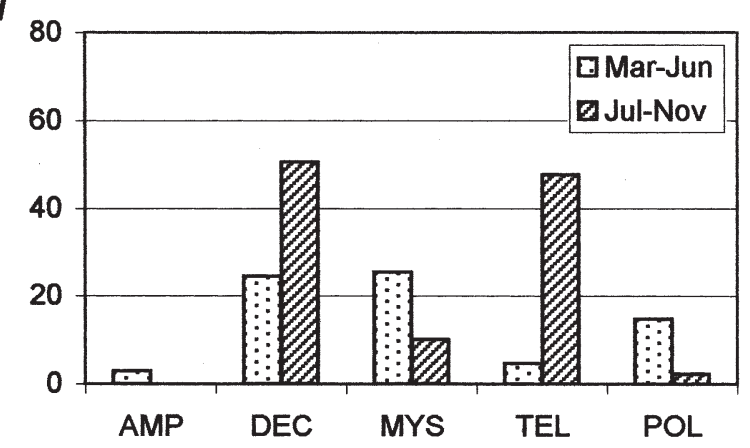

FIG. 3. - Relative importance of the main food items in the diet of A. imperialis in the periods from March to June and from July to November, based on numerical (NI) and gravimetric (GI) indices (AMP: Amphipoda; DEC: Decapoda; MYS: Mysidacea; TEL: Teleostei; POL: Polychaeta).
March to June, while from July to November, Decapoda were more abundant in the diets (Figs. 3, 4, 5 and 6). For A. thori, Mysidacea were also more important in the period from March to June, compared to the other period (Fig. 5). In the diet of $B$. luteum, Bivalvia, Cumacea and Polychaeta occurred in higher number from March to June (Fig. 6).

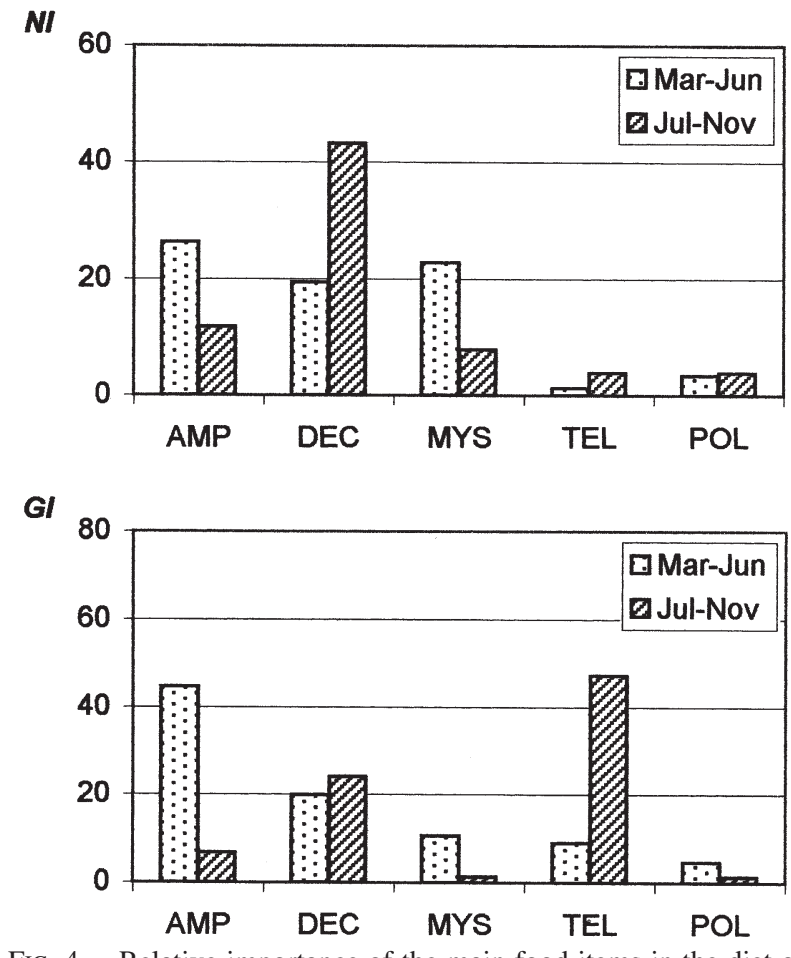

FIG. 4. - Relative importance of the main food items in the diet of A. laterna in the periods from March to June and from July to November, based on numerical (NI) and gravimetric (GI) indices (AMP: Amphipoda; DEC: Decapoda; MYS: Mysidacea; TEL: Teleostei; POL: Polychaeta). 
N

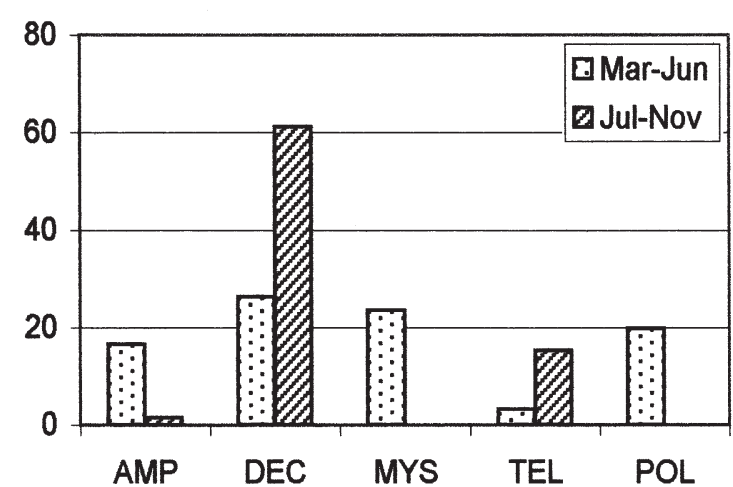

GI

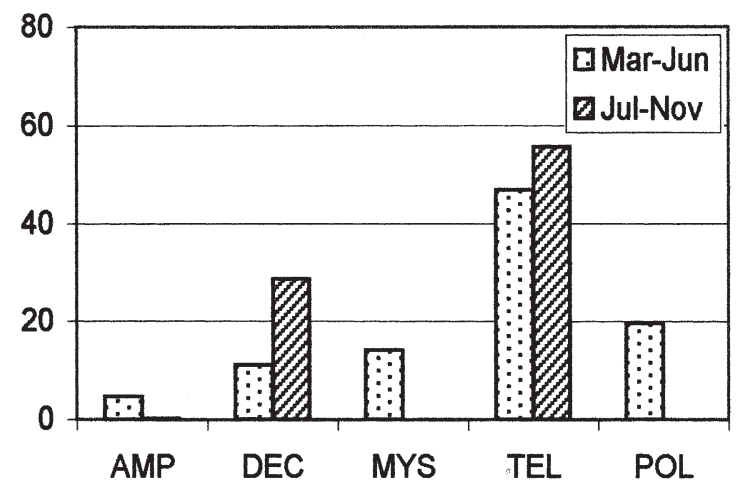

FIG. 5. - Relative importance of the main food items in the diet of A. thori in the periods from March to June and from July to November, based on numerical (NI) and gravimetric (GI) indices (AMP: Amphipoda; DEC: Decapoda; MYS: Mysidacea; TEL: Teleostei; POL: Polychaeta).
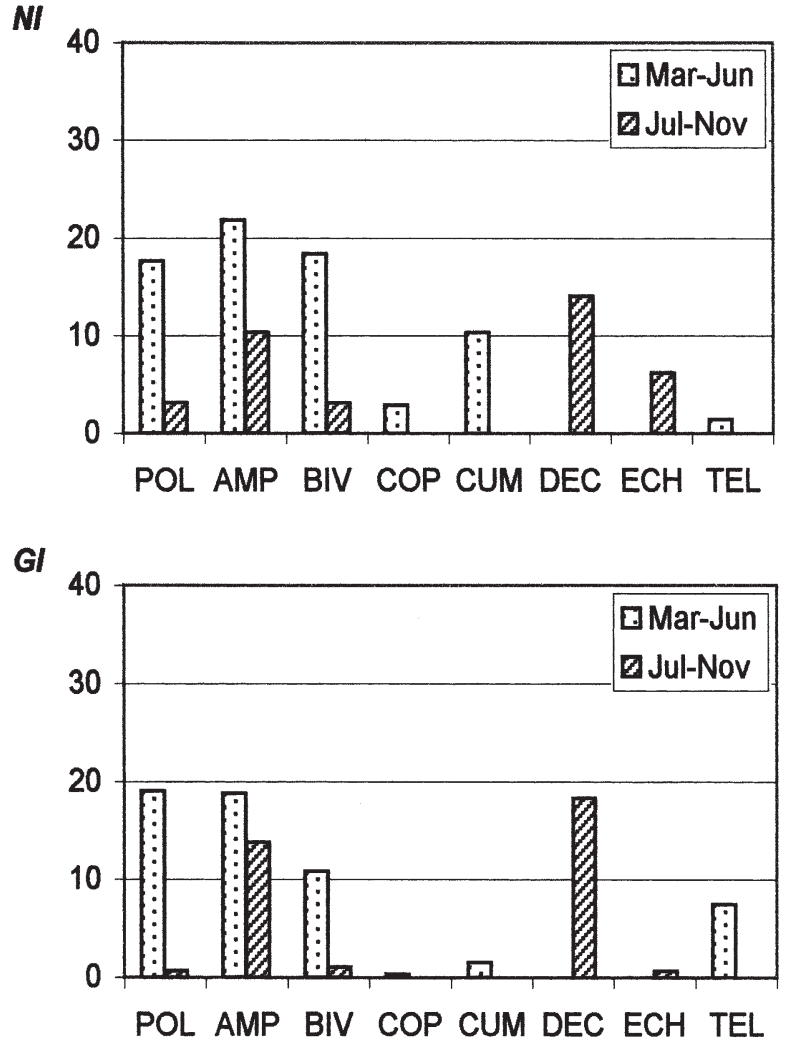

FIG. 6. - Relative importance of the main food items in the diet of B. luteum in the periods from March to June and from July to November, based on numerical (NI) and gravimetric (GI) indices (POL: Polychaeta; AMP: Amphipoda; BIV: Bivalvia; COP: Copepoda; CUM: Cumacea; DEC: Decapoda; ECH: Echinodermata; TEL: Teleostei;).

TABLE 3. - Schoener index values of trophic niche overlap between the different flatfish species, based on NI (upper triangular matrix) or GI (lower triangular matrix) data (* values higher than 0.6$)$.

\begin{tabular}{|c|c|c|c|c|c|c|c|}
\hline & A. imperialis & A. laterna & A. thori & B. luteum & D. cuneata & S. rhombus & P. lascaris \\
\hline A. imperialis & - & 0.50 & 0.41 & 0.33 & 0.18 & $0.91 *$ & 0.24 \\
\hline A. laterna & $0.74 *$ & - & $0.78 *$ & 0.58 & 0.33 & 0.42 & 0.47 \\
\hline A. thori & $0.81 *$ & $0.73 *$ & - & 0.58 & 0.38 & 0.32 & 0.41 \\
\hline B. luteum & 0.55 & $0.63 *$ & 0.58 & - & $0.66 *$ & 0.28 & $0.67 *$ \\
\hline D. cuneata & 0.48 & 0.47 & 0.46 & $0.78 *$ & - & 0.13 & 0.37 \\
\hline S. rhombus & $0.72 *$ & 0.57 & 0.55 & 0.35 & 0.30 & - & 0.15 \\
\hline P. lascaris & 0.52 & 0.54 & 0.48 & $0.73 *$ & $0.63 *$ & 0.39 & - \\
\hline
\end{tabular}

\section{Dietary overlap}

According to NI and GI values, diet overlap was higher than 0.6 between $A$. thori and A. laterna, $D$. cuneata and B. luteum, B. luteum and P. lascaris and S. rhombus and A. imperialis (Table 3).

Considering GI values, overlap between $A$. imperialis and A. laterna, A. imperialis and A. thori, $B$. luteum and A. laterna and D. cuneata and P. lascaris were also high according to the 0.6 critical value (Table 3).

\section{DISCUSSION}

The analysis of the diets of the seven flatfish species considered in the present work revealed that the relative importance of each prey was considerably different according to species. Nonetheless, two main groups of species were identified based on diet similarity: one composed of A. imperialis, A. laterna, A. thori and $S$. rhombus, i.e. the Bothidae and Scophtahlmidae species, and the other grouping $B$. luteum, D.cuneata and S. lascaris, i.e. the Soleidae species. 
Differences in the feeding behavior between Pleuronectiformes families have been pointed out by several authors, namely de Groot (1971), Braber and de Groot (1973) and Holmes and Gibson (1983). Bothidae and Scophthalmidae are day-active predators using visual cues for food detection, responding primarily to moving prey, and thus feeding mainly on active rather than sedentary prey, while Soleidae are basically night feeders consuming less mobile or sedentary prey (de Groot, 1971; Braber and de Groot, 1973).

For A. imperialis, A. laterna and A. thori, Amphipoda, Decapoda Polychaeta and Mysidacea were the main prey, although their importance varied according to species. Gibson and Ezzi (1980), in a study conducted in the Scottish coast, described a similar diet composition for A. laterna (based on individuals from $26 \mathrm{~mm}$ to $142 \mathrm{~mm}$ total length), except in the importance of Amphipoda that were considered a secondary prey by these authors. Avsar (1994), in Turkey, outlined that the diet of A. laterna, of about the same size range, was composed by Decapoda, Amphipoda, Mysidacea, Euphausiacea, Copepoda, Teleostei and Nematoda, by decreasing order of importance. Deniel (1975), when comparing the diet of A. imperialis and $A$. thori in north France, reported that the diet of $A$. thori were dominated by Philocheras spp. (Crangonidae) and Schistomysis spp. (Mysidacea). According to this author the diet of A. imperialis presented a higher percentage of fish, mainly Callionymus lyra, comparated to the other two species. These results do not corroborate the dominance of Mysidacea in the diet of A. imperialis found in the present work. However, this could be due to differences in the size of the individuals sampled, since in larger individuals the importance of fish in the diet increases while that of Mysidacea decreases (Deniel, 1975).

For B. luteum, a diet based on Amphipoda, Polychaeta and Bivalvia was also reported by Nottage and Perkins (1983) and Darnaude et al. (2001). Although the lengths of the individuals analyzed were considerably different in these two studies (59 to $130 \mathrm{~mm}$ and 20 to $99 \mathrm{~mm}$ total length, respectively), these authors agree on the importance of Copepoda in the diet of $B$. luteum, which were not found in the stomachs analyzed in the present work.

Belghyti et al. (1993) noticed that the diet of $D$. cuneata, on the Moroccan Atlantic coast, presented a wide variety of prey (55 species, belonging to 42 different families), with the most important items being Amphipoda, Polychaeta and Decapoda. The preponderance of Mysidacea and Teleostei in the diet of young $S$. rhombus was also emphasized by Braber and de Groot (1973) and Beyst et al. (1999), in the North Sea. Finally, considerable differences can be outlined when comparing the diet of P. lascaris in the Mediterraean (Marinaro and Bouabid, 1983) with that described in the present work. According to Marinaro and Bouabid (1983), Amphipoda were the main prey of $P$. lascaris, followed by Isopoda, Mysidacea, Tanaidacea and Polychaeta. However, the number of stomachs analyzed by these authors was particularly low (less than 25 stomachs with food), which could bias the estimation of prey importance.

The seasonal variation pattern found in the diets of A. imperialis, A. laterna, A. thori and B. luteum was similar: Amphipoda presented a higher importance from March to June, while Decapoda were more heavily consumed from July to November. Previous studies on the feeding ecology of the flatfish considered in the present work reported different results, in large extent due to particularities of the study site, variety of habitats and even range of fish lengths analyzed (e.g. Nottage and Perkins, 1983; Belghyti et al., 1993; Darnaude et al., 2001).

The feeding activity of all the species studied here was quite high (the percentage of empty stomachs was lower than 15\%), which has also been pointed out by several authors (e.g. Marinaro and Bouabid, 1983; Nottage and Perkins, 1983; Belghyti et al., 1993), although the feeding activity may vary considerably according to season.

Diet overlap has been reported within juvenile flatfish assemblages in other geographical areas (e.g. Breyst et al., 1999; Cabral, 2000b; Darnaud et $a l ., 2001)$. The existence of trophic niche overlap does not necessarily cause interspecific competition. The main items in the diet of juvenile flatfishes in these coastal assemblages are generally the most abundant prey (e.g. Beyst et al., 1999; Cabral 2000b; Darnaude et al., 2001), which emphasizes a generalist and an opportunistic utilization of these food resources (Lasiak and McLachlan, 1987; Beyst et al., 1999). Furthermore, niche overlap is usually minimized by differences in resource use in other niche dimensions, namely time and space (Moore and Moore, 1976; Poxton et al., 1983; Burke, 1995).

Darnaud et al. (2001) studied the food portioning among juvenile flatfishes in a Mediterranean coastal shallow area and found that diet overlap was low. According to these authors, differences in feeding rhythms, food preferences and body sizes, reduced the direct food competition, allowing the coexis- 
tence of several flatfish juveniles within the same nursery zone, despite close periods of settlement.

Previous studies in the Tagus estuary nursery grounds also suggested that a differential use of these areas by sympatric $S$. solea and Solea senegalensis Kaup, 1858, may reduce intra- and interspecific competition (Cabral and Costa, 1999; Cabral, 2000b). Furthermore, the differences in the diel variation pattern of the feeding activity described above, i.e. Bothidae and Scophthalmidae are day-active predators, while Soleidae are night feeders (de Groot, 1971), surely contribute to reduce niche overlap.

The development of quantitative approaches in order to evaluate prey availability and predation pressure is of particular importance for a better understanding of the structure and dynamics of coastal nursery areas.

\section{REFERENCES}

Aarnio, K., E. Bonsdorff and N. Rosenback. - 1996. Food and feeding habits of juvenile flounder Platichthys flesus (L.), and turbot Scophthalmus maximus L. in the Aaland Archipelago, northern Baltic Sea. J. Sea Res., 36: 311-320.

Avsar, D. - 1994. Diel diet and feeding behaviour of scaldfish (Arnoglossus laterna Walbaum, 1972) in the Bay of Mersin. Acta Adriat., 34: 89-101.

Belghyti, D., P. Aguesse and C. Gabrion. - 1993. Éthologie alimentaire de Citharus linguatula et Dicologoglossa cuneata sur les côtes atlantiques du Marroc. Vie Milieu, 43: 95-108.

Beyst, B., A. Cattrijsse and J. Mees. - 1999. Feeding ecology of juvenile flatfishes of the surf zone of a sandy beach. J. Fish Biol., 55: 1171-1186.

Blaber, S.J.M. and T.G. Blaber. - 1980. Factors affecting the distribuition of juvenile estuarine and inshore fish. J. Fish Biol., 17: 143-162.

Braber, L. and S.J. de Groot. - 1973. The food of five flatfish species (Pleuronectiformes) in southern North Sea. Neth. J. Sea Res., 6: 163-172.

Burke, J.S. - 1995. Role of feeding and prey distribution of summer and southern flounder in selection of estuarine nursery habitats. J. Fish Biol., 47: 355-366.

Cabral, H.N. - 2000a. Distribution and abundance patterns of flatfishes in the Sado estuary, Portugal. Estuaries, 23: 351-358.

Cabral, H.N. - 2000b. Comparative feeding ecology of two sympatric soles, Solea solea and Solea senegalensis, within the nursery areas of the Tagus estuary. J. Fish Biol., 57: 1550-1562.

Cabral, H.N. and M.J. Costa - 1999. Differential use of the nursery areas within the Tagus estuary by sympatric soles, Solea solea (Linnaeus, 1758) and Solea senegalensis Kaup, 1858. Env. Biol. Fishes, 56: 389-397.

Cabral, H.N., J. Duque and M.J. Costa. - 2000. Importance of the coastal zone adjacent to the Tagus estuary as a nursery area for fish. Thalassas, 16: 27-32.

Cabral, H.N. and A.G. Murta - 2001. The diet of blue whiting, hake, horse mackerel and mackerel off Portugal. J. Appl. Ichthyol., 17: 1-10.

Costa, M.J. and A. Bruxelas. - 1989. The structure of fish communities in the Tagus Estuary, Portugal, and its role as a nursery for commercial fish species. Sci. Mar., 53: 561-566.

Darnaude, A.M., M.L. Harmelin-Vivien and C. Salen-Picard. 2001. Food portioning among flatfish (Pisces: Pleuronectiforms) juveniles in a Mediterranean coastal shallow area. $J$. Mar. Biol. Ass. U. K., 81: 119-127.

de Groot, S.J. - 1971. On the interrelationships between morphology of the alimentary tract, food and feeding behaviour in flatfishes
(Pisces: Pleuronectiformes). Neth. J. Sea Res., 5: 121-196.

Deniel, C. - 1975. Regimes alimentaires d'Arnoglossus thori Kyle et d'Arnoglossus imperialis Rafinesque (Teleosteens-Bothidae) en Baie de Douarnenez. Rev. Trav. Inst. Pêches Marit. Nantes, 39: 105-116.

Elliott, M. and F. Dewailly. - 1995. The structure and components of european estuarine fish assemblages. Neth. J. Aquat. Ecol., 29:397-417.

Gibson, R.N. and I.A. Ezzi. - 1980. The biology of the scaldfish, Arnoglossus laterna (Walbaum) on the west coast of Scotland. J. Fish Biol., 17: 565-575.

Haedrich, R.L. - 1983. Estuarine fishes. In: B. Ketchum (ed.), Ecosystems of the world. 26 - Estuaries and enclosed seas, pp. 183-207, Elsevier, Amsterdam.

Holmes, R.A. and R.N. Gibson. - 1983. A comparison of predatory behavior in flatfish. Animal Behavior, 31: 1244-1255.

Hyslop, E.J. - 1980. Stomach contents analysis: a review of methods and their application. J. Fish Biol., 17: 415-429.

Knust, R. - 1990. Food and condition of dab Limanda limanda (L.) from Dogger Bank and the German Bight. ICES CM, G:62.

Lagardère, J.P. - 1987. Feeding ecology and daily food consumption of common sole, Solea vulgaris Quensel, juveniles on the French Atlantic coast. J. Fish Biol., 30: 91-104.

Lasiak, T.A. and McLachlan, A. - 1987. Opportunistic utilization of mysid shoals by surf-zone teleosts. Mar. Ecol. Prog. Ser., 37: 1-7.

Lenanton, R.C.J. - 1982. Alternative non-estuarine nursery habitats for some commercially and recreationally important fish species of South-western Australia. Aust. J. Mar. Freshw. Res., 33: 881-900

Linton, L.R., R.W. Davies and F.J. Wrona. - 1981. Resource utilization indices: an assessment. J. Animal Ecol., 50: 283-293.

Marinaro, J.Y. and M. Bouabid. - 1983. Ecologie alimentaire de deux soles d'Algérie, Pegusa nasuta (Pallas) et $P$. lascaris (Risso) (Téléostéens soléidés). Rapp. Comm. Int. Mer Médit., 28: 73-75

Mathieson, S., A. Cattrijsse, M.J. Costa, P. Drake, M. Elliott, J. Gardner and J. Marchand. - 2000. Fish assemblages of European tidal marshes: a comparison based on species, families and functional guilds. Mar. Ecol. Prog. Ser., 204: 225-242.

Miller, J.M. and M.L. Dunn. - 1980. Feeding strategies and patterns of movement in juvenile estuarine fishes. In: V.S. Kennedy (ed.), Estuarine perspectives, pp. 437-448. Academic Press, New York.

Moore, J.W. and I.A. Moore. - 1976. The basis of food selection in flounders, Platichthys flesus (L.), in the Severn estuary. J. Fish Biol., 9: 139-156.

Nottage, A.S. and E.J. Perkins. - 1983. The biology of the solenette, Buglossidium luteum (Risso), in the Solway Firth. J. Fish Biol., 22: 21-27.

Poxton, M.G., A. Eleftheriou and A.D. McIntyre. - 1983. The food and growth of 0-group flatfish on nursery grounds in the Clyde Sea area. Est. Coast. Shelf Sci., 17: 319-337.

Putman, R.J. - 1994. Community ecology. Chapman and Hall, London. Quéro, J.C., M. Desoutter and F. Lagardère. - 1986. Soleidae. In: P.J.P. Whitehead, M.L. Bauchot, J.C. Hureau, J. Nielsen and E. Tortonese (eds.), Fishes of the North-eastern Atlantic and Mediterranean, pp. 1308-1324, Unesco, Paris.

Ramos, J. - 1981. Régimen y comportamiento alimentario del lenguado (Solea solea L.) (Pisces, Soleidae). Inf. Técn. Inst. Inv. Pesq., 83: 3-15.

Ross, S.T. - 1986. Resource portioning in fish assemblages: a review of field studies. Copeia, 1986: 352-388.

Schoener, T.W. - 1974. Resource portioning in ecological communities. Science, 185: 27-39.

Summers, R.W. - 1980. The diet and feeding behavior of the flounder Platichthys flesus (L.) in the Ythan estuary, Aberdeenshire, Scotland. Est. Coast. Mar. Sci., 11: 217-232.

Thorman, S. and A.M. Wiederholm. - 1986. Food, habitat and time niches in a coastal fish species assemblage in a brackish water bay in the Bothnian Sea, Sweden. J. Exp. Mar. Biol. Ecol., 95: 67-86.

Wallace, H. - 1981. An assessment of diet overlap indexes. Trans. Am. Fish. Soc., 110: 72-76.

Wallace, H. and J.S. Ramsay. - 1983. Reliability in measuring diet overlap. Can. J. Fish. Aquat. Sci., 40: 347-351.

Zar, J. - 1996. Biostatistical analysis. 3rd ed. Prentice Hall, Engelwood Cliffs.

Scient. ed.: E. MacPherson 